\title{
Antithrombotic drugs
}

Citation for published version (APA):

Hemker, H. C., Giesen, P. L. A., Wagenvoord, R., \& Beguin, S. (1999). Antithrombotic drugs. Expert opinion on emerging drugs, 4(1), 175-195. [8]. https://doi.org/10.1517/14728214.4.1.175

Document status and date:

Published: 01/01/1999

DOI:

10.1517/14728214.4.1.175

Document Version:

Publisher's PDF, also known as Version of record

\section{Please check the document version of this publication:}

- A submitted manuscript is the version of the article upon submission and before peer-review. There can be important differences between the submitted version and the official published version of record.

People interested in the research are advised to contact the author for the final version of the publication, or visit the DOI to the publisher's website.

- The final author version and the galley proof are versions of the publication after peer review.

- The final published version features the final layout of the paper including the volume, issue and page numbers.

Link to publication

\footnotetext{
General rights rights.

- You may freely distribute the URL identifying the publication in the public portal. please follow below link for the End User Agreement:

www.umlib.nl/taverne-license

Take down policy

If you believe that this document breaches copyright please contact us at:

repository@maastrichtuniversity.nl

providing details and we will investigate your claim.
}

Copyright and moral rights for the publications made accessible in the public portal are retained by the authors and/or other copyright owners and it is a condition of accessing publications that users recognise and abide by the legal requirements associated with these

- Users may download and print one copy of any publication from the public portal for the purpose of private study or research.

- You may not further distribute the material or use it for any profit-making activity or commercial gain

If the publication is distributed under the terms of Article $25 \mathrm{fa}$ of the Dutch Copyright Act, indicated by the "Taverne" license above, 


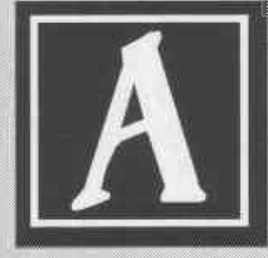

http://www-astley-pub.com

\section{Review}

1. Summary

2. Background

3. Medical need

3.1 Existing treatment

4. Therapeutic class review

4.1 Direct thrombin inhibitors

4.2 Direct inhibitors of other clotting enzymes

4.3 Platelet inhibitors

5. Current research goals

5.1 Laboratory models for the function of the HTS

5.2 Clotting times

5.3 Platelet tests

5.4 The thrombin generation curve

6. Scientific rationale

7. Potential development issues

7.1 Catalysts of physiological inhibition

7.2 Direct inhibitors

7.3 Platclet inhibitors

8. Editorial analysis Bibliography
Emerging Drugs: The Prospect for Improved Medicines

Annual Executive Briefing 1999
Chapter Eight

\section{Antithrombotic drugs}

\author{
H Coenraad Hemker, Peter LA Giesen, Robert Wagenvoord \& \\ Suzette Béguin
}

Cardiovascular Research Institute (CARIM), Maastricht, The Netherlands

Emerging Drugs (1999) 4:175-195

\section{Summary}

The haemostatic-thrombotic system (HTS) can be inhibited at dozens of different sites by hundreds of different drugs. The ideal antithrombotic is an inhibitor that downregulates the HTS without causing bleeding or other side-effects, and that can be given orally in a fixed dose. These are pharmacological criteria. Indeed, the three current therapies (heparins, oral anticoagulant therapy and aspirin) act by completely different mechanisms. It is not the mechanism of inhibition which is important but the pharmacological properties of the inhibitor; no compound has been found that inhibits the HTS and does not show an antithrombotic effect.

The HTS is a non-linear system containing a number of nested positive and negative feedback loops. At the present state of knowledge it is impossible to predict the effect of inhibition of a single reaction on the response of the complete system. For this reason one cannot predict the antithrombotic potency of a compound from its biochemical properties. It is shown that clotting tests, measurement of platelet aggregation/adhesion or tests of individual functions within the system are only of limited use. Antithrombotics therefore should be evaluated by their action on a representative function test of the complete HTS. Such a test is not routinely available at the moment. Two promising possibilities are flow chambers using non-anticoagulated blood and thrombin generation in blood or platelet rich plasma (PRP).

\section{Background}

Thrombosis is caused by the same mechanism that causes haemostasis. Administering antithrombotic drugs therefore requires careful manipulation of the balance between thrombosis and bleeding. For the safe use of 
antithrombotic drugs, we need a probe for the functional status of the HTS. Such a test is not routinely available at this moment. Bleeding times are hopelessly inaccurate [1] and clotting times are to be considered surrogate variables of limited use. There is no general test to indicate hypercoagulability and thrombosis risk, or to monitor the effect of antithrombotic treatment. Current management of thrombosis is like managing diabetes by the taste of the urine, or hypertension with only a pulse to feel.

This situation has an immediate influence on the search for new antithrombotic drugs. There is no easy, valid laboratory test to indicate therapeutic efficacy or optimal dosage. The research goal is defined in terms like 'doubling the activated partial thromboplastin time (aPTT)' or 'inhibition of platelet aggregation' that have, at the best, a semiquantitative relation to haemostasis and thrombosis. Further testing is in animal thrombosis models and, eventually, clinical trials.

In this article we will defend the position that it is unimportant how the function of the HTS is inhibited as long as the inhibition fulfils certain pharmacological criteria. Consequently, we will not dwell in detail on individual mechanisms of inhibition or on inhibitor design. Rather we will stress the importance of assessing HTS function as a whole.

\section{Medical need}

In recent years it has been firmly established that virtually every arterial occlusive event (such as myocardial or cerebral infarction) is due to the formation of a local thrombus on a damaged internal surface of the vessel. Thrombin plays an all-important role in this process [2-6]. A damaged wall exposes triggers for thrombosis, such as tissue factor (TF) present in the smooth muscle cells of neointima [7], in the adventitia and in the plaque [8-10], as well as the platelet-activating collagen surface [11]. Non-occlusive arterial thrombosis may lead to downstream occlusion if the thrombus is carried with the bloodstream. In strategic positions, such as the carotid arteries, this may have serious consequences. Arterial thrombosis is not only the consequence of atherosclerosis; through microthrombus formation it also plays a role in the development of arterial wall degeneration. Furthermore, venous thrombosis and its sequelae, ranging from sudden death due to pulmonary embolism to chronic leg-ulcers, is not a negligible source of illness. At this moment, in the Western World, arterial and venous thrombosis and atherosclerosis together are responsible for well over $50 \%$ of all mortality and serious morbidity. In a few decades this will be the case worldwide [12]. Good antithrombotic drugs, therefore, are a necessity.

\subsection{Existing treatment}

\subsubsection{Heparins}

Heparins, either unfractionated (UFH) or of the low molecular weight type (LMWH) [14], reduce the incidence of thrombosis by about $50 \%$. They have the drawback of parenteral administration. They may cause antithrombin (AT) deficiency, thrombocytopenia, bleeding and a few more rare side-effects. The methods for laboratory control of heparin dosage, notably the aPTT, are inadequate. The question of whether adapted doses of heparin would do better than current practice remains unsolved because control methods to guide the adaptation are not available. Prolonged heparin treatment, in particular with $\mathrm{UFH}$, is not favoured. 


\subsubsection{Oral anticoagulation}

Oral anticoagulation $(\mathrm{OAC})$ is maintained with coumarin congeners, i.e., anti-vitamin $\mathrm{K}$ drugs. They inhibit the oxidation reduction cycle of vitamin $\mathrm{K}$ in the liver, required for the normal $\gamma$-carboxylation of the clotting Factors II, VII, IX and X, protein C and protein S. There are large variations in individual need and many drug interactions (e.g., with sleeping pills and alcohol). Therefore, regular control of the level of anticoagulation is necessary. This can be readily carried out via determination of the thromboplastin time and expressing the result as an international normalised ratio (INR).

\subsubsection{Aspirin}

Aspirin is the only antiplatelet drug in general use. The effect is dose-independent between 40 and $1000 \mathrm{mg} /$ day. There are few complications seen. The protective effect in venous thrombosis is not significant and in arterial thrombosis it is modest $(10-20 \%)$. Ticlopidine and clopidogrel (Iscover ${ }^{\mathrm{TM}}$, Plavix ${ }^{\mathrm{TM}}$ ) are alternative possibilities. Abciximax, the antibody against the fibrinogen receptor of plasma, is used in acute coronary infarction.

\section{Therapeutic class review}

Heparins are glycosaminoglycans with molecular weights ranging from 1500 to $100,000 \mathrm{Da}$ [14]. Those that contain a specific pentasaccharide sequence bind to AT and catalyse the irreversible inhibition of activated clotting factors by this plasma protein. The inhibitory capacity of AT towards thrombin is roughly three times that towards Factor Xa; that towards IXa and XIa is smaller and probably without practical significance. The relative activity against the different factors is not changed by heparin, with one notable exception: heparins smaller than $5400 \mathrm{Da}$ will not cause inactivation of thrombin, but do catalyse that of Factor Xa. Inhibition of Factor Xa is an inefficient way to inhibit thrombin formation. LMWHs contain a fair amount of molecules of $<5400 \mathrm{Da}$, whereas UFH does not; therefore LMWHs have a higher anti-Xa activity than UFH. The difference is small in the presence of $\mathrm{Ca}^{++}$ions (i.e., in vivo) but appears much larger in the usual in vitro test, where $\mathrm{Ca}^{++}$is absent [15]. A high anti-Xa activity has been the guideline in searching for efficient LMWHs [14]. Despite the inefficiency of Factor $\mathrm{Xa}$ inhibition this has led to useful products, because preparations with a high anti-Xa activity also contain a large proportion of material in the $5400-9000 \mathrm{Da}$ range. Such material is an efficient anticoagulant because of its persistent AT activity, together with a high bioavailability after sc. injection $[16,17]$. It has also been surmised that the very large molecular weight components present in UFH, but not in LMWH, have specific haemorrhagic properties [18]. In retrospect, the anti-Xa activity must be considered largely an artefact; LMWHs are good drugs developed on the basis of a mistaken concept.

AT only partially inhibits clot-bound thrombin, if at all. Heparin co-factor II (HCII) [19] is capable of inhibiting this thrombin, but only in the presence of relatively high concentrations of acid polysaccharides (dermatan sulfate, pentosan polyphosphate, lactobionic acid, etc.) [20-24]. Heparin can also activate $\mathrm{HCII}$, but at doses much higher than the normal
therapeutic and preventive ones.

\subsection{Direct thrombin inhibitors}

The prototype of direct thrombin inhibitors is hirudin [25-28], which has proven its value in experimental thrombosis as well as in clinical trials. Indeed direct thrombin inhibition is a feasible route to obtain antithrombotic action [6,29-33]. Modern techniques of 
combinatorial chemistry can construct large peptide derivative libraries and facilitate the search for specific inhibitors [34,35]. There is also continuous interest in natural inhibitors from haematophagous animals and other sources [36-40], CVS1123 [41], inogatran (HA-31427) [42-44], melagatran (H-31968) [42-47] and napsagatran (Ro-46-6240) [48], and a large variety of others [49-65]. Some have been tested in the clinical situation. Most of them are administered parenterally, but oral administration is feasible [66]. The overall impression is that, like hirudin, they can replace heparin, without showing obvious advantages except their use in AT deficiency and their ability to inactivate clot-bound thrombin $[44,49,67,68]$.

There is an essential difference between irreversible thrombin inhibitors (such as hirudin) and reversible ones (such as argatroban [Novastan ${ }^{\mathrm{TM}}$ ]). The irreversible ones bind with 1:1 stoichiometry to thrombin. If drug administration is stopped, the inactivated thrombin molecules remain inhibited. Serious bleeding problems are to be expected as soon as the concentration of an irreversible inhibitor approaches the level of prothrombin in plasma $(\sim 2 \mu \mathrm{M})$, so that all the thrombin that can be formed is immediately inhibited. Reversible inhibitors bind a fraction of the available thrombin; the proportion inhibited is dependent upon the inhibition constant $\left(K_{i}=\right.$ the concentration at which half-maximal inhibition is observed) and upon the concentration of the inhibitor. If the concentration of the inhibitor decreases, the inhibition is relieved. Reversible inhibitors probably act because they diminish thrombin concentration at the site of thrombosis, where thrombin formation is triggered. They will enter into competition with the natural substrates of thrombin (procoagulants: e.g., fibrinogen; Factors V, VIII, XI; platelets, as well as anticoagulants: e.g., thrombomodulin). All reversibly inhibited thrombin molecules will be eventually released and taken over by natural, irreversible inhibitors (e.g., AT). So, irreversible inhibitors arrest thrombin action and reversible ones dampen it. Both mechanisms seem to lead to antithrombotic activities. It is unknown to the authors whether there are fundamental differences in haemorrhagic properties.

\subsection{Direct inhibitors of other clotting enzymes}

A large number of natural and synthetic inhibitors of Factor Xa has been described [35,69-86]. The original idea behind their development was that it is more efficient to inhibit thrombin production ('closing the tap') than thrombin itself ('mopping the floor'). This view, based upon the early concepts of the clotting cascade as a linear mechanism, became untenable as soon as it was realised how important thrombin-mediated feedback reactions are and how important Factor Xa is for the inhibition of the TF Factor VIIa complex (TF-VIIa) via tissue factor pathway inhibitor (TFPI). Also, Factor Xa has to be inhibited by $90 \%$ in order to inhibit prothrombin conversion by about $50 \%$.

Inhibition of the first step in thrombin generation, i.e., at the level of Factor VIIa and TF, is also possible [87-89]. An interesting concept is the inhibition of TF by the administration of recombinant, active site-inhibited Factor VIIa [90-92], or by peptides that mimic part of this molecule [93].

All VIIa and Xa inhibitors tested appear capable of inhibiting experimental thrombosis (e.g., [94-96]). They have not yet been used in the clinic, and it is not established whether they show specific advantages. However, an important finding has recently been made that shows that circulating TF plays a role in the formation of the thrombus [170]. A competitive VIIa inhibitor could inhibit this thrombus formation. Theoretically, this approach towards thrombus prevention would have a broad therapeutic range since the amount of circulating 
TF is much easier to inhibit than the local TF exposure after vessel damage, thus minimising bleeding risk.

The main result from research on direct inhibitors as a group is that any inhibitor of the clotting system, independent of the enzyme that it attacks or of the mode of inhibition is antithrombotic, in any thrombosis model.

\subsection{Platelet inhibitors}

Many excellent reviews on platelet inhibitors have been published [ e.g., 97,98]. Aspirin, in all probability, acts by irreversibly inhibiting cyclooxygenase and, thereby, platelet thromboxane $\mathrm{A}_{2}\left(\mathrm{TXA}_{2}\right)$ synthesis [99]. Other non-steroidal anti-inflammatory drugs (NSAIDs) and sulfinpyrazone inhibit the same enzyme reversibly. Dipyridamole increases intraplatelet cyclic AMP (cAMP) [99-101], as do prostaglandin E1 and prostacyclin (which, due to its instability, is of limited therapeutic use) $[102,103]$. Stable analogues of the latter are iloprost (SH-401) [104,105] and ciprostene (U-61431F) [106]. Thromboxane synthase inhibitors and inhibitors of the thromboxane receptor are of doubtful efficiency [107]. Ketanserin, one of the group of serotonin receptor antagonists seems to do no better [108,109].

Inhibitors of the ADP receptor, such as ticlopidine [110-113] or clopidogrel [114], are better than aspirin and may be combined with it. Inhibitors of the platelet fibrinogen receptor glycoprotein (GP) $\mathrm{Ib} / \mathrm{IIl}$ a have shown promising results [115-119].

Platelet inhibitors have been developed as inhibitors of adhesion or aggregation. Recently, it appeared that all those tested hitherto also inhibit thrombin generation in PRP. Aspirin, for example, causes an inhibition of about $10 \%$, roughly equal to the reduction of arterial thrombosis that is seen in large clinical trials. Prostacyclin analogues also inhibit thrombin generation in PRP [120] (unpublished observations). Inhibition of GP IIb/IIa, the fibrinogen receptor of the platelet membrane, reduces thrombin generation by about $50 \%$ $[121,122]$. Administration of these inhibitors produces the same defect as is congenitally present in Glanzmann's thrombasthenia, a disease in which a diminution of thrombin generation is observed [121,122]. Also, inhibition of von Willebrand factor (vWF), GP Ib and the vWF receptor strongly inhibits thrombin generation in PRP [123,124]. Thrombin generation in PRP is evidently also dependent upon the function of the plasmatic clotting factors and upon the interactions between plasma and platelets. This suggests that thrombin generation in PRP and/or blood might be a good screening technique for antithrombotics, independent of whether they act via the platelet or as anticoagulants.

\section{Current research goals}

The ultimate research goal is an antithrombotic that decreases the incidence of thrombosis (of any type) by more than $50 \%$, that can be administered orally, that is immediately active, that can be given in a standard dosage without requiring laboratory control and that does not cause bleeding when overdosed. None of the available antithrombotics fulfil these criteria.

The complicated HTS lends itself to inhibition at a large number of sites, each of them a potential target for pharmacological action. The three established therapies have completely different modes of action. Multiple other modes of inhibition have been shown to work in experimental thrombosis. This proves that the desired goal can be attained in many different ways. The question of what specific target in the HTS should be attacked in 
order to obtain the ideal antithrombotic is often posed. It is mostly answered a priori by theoretical considerations that need to be corroborated a posteriori by animal thrombosis experiments. The result, as stated, is that any inhibition entails antithrombotic activity. Advanced knowledge of the subsystems of the HTS may, in the long run, give the answer. This goal is not within easy reach however. At this moment, it would be more useful to conceive of a screening test that represents total HTS function, and that is simpler and less expensive than animal thrombosis models.

\subsection{Laboratory models for the function of the HTS}

The ideal model, like real thrombosis, should respond in a similar way to clinically effective concentrations of all antithrombotics independent of the moleculr focus of their effect. This means that clotting times in PRP (and a fortiori inhibition tests of individual clotting factors), platelet aggregation or adhesion tests carried out in anticoagulated PRP, are not reasonable options. In view of their widespread use, we will nevertheless discuss clotting times in more detail.

\subsection{Clotting times}

Blood (plasma) clots when more than $95 \%$ of the prothrombin is still to be converted [120]. Clotting times do not reflect the amount of thrombin that is still to be formed at the moment of clotting. Yet it is the amount of thrombin that determines the extent of the thrombotic reaction. Therefore, a clotting time will not reflect directly the relevant parameter. This is also seen from the fact that a different type of clotting time is required for estimating the effect of different types of anticoagulants. The thromboplastin time or 'prothrombin time' (PT), for example, indicates the depth of oral anticoagulation but is not sensitive to the effect of heparin. The aPTT is particularly sensitive to variations in the concentration and/or activity of Factor VIII and UFH, but not to LMWH and activators of HCII. Doubling the aPTT is thought to represent adequate heparin administration. This is based on very limited studies in animals [125] and man [126,127]. There is no relation between recurrent thromboembolism and the aPTT response [128]. The mechanism by which direct thrombin or Factor Xa inhibitors prolong the aPTT is significantly different from that of heparin [129]. Nevertheless 'doubling the aPTT' is also used as an indicator for therapeutic action with any type of clotting inhibitor. We conclude that clotting tests are not a valid general indicator of antithrombotic action. This does not mean that they cannot be used in special cases: the thromboplastin time is a good indicator of oral anticoagulation [130] and the Ecarin time is useful in assessing the level of direct thrombin inhibitors [131,132].

\subsection{Platelet tests}

Platelet aggregation and flow-chamber or other tests that are carried out on washed platelets or on PRP in which the coagulation mechanism has been inhibited, will not reflect interactions between platelets and the clotting system, and therefore are of limited use [133-135]. Experiments in which non-anticoagulated blood is passed through a flow chamber containing a thrombogenic surface are not subject to this drawback. A model system that tries to mimic the concert of thrombotic triggers and flow parameters has been developed [136-140]. A flow chamber is directly coupled to the antecubital vein of a volunteer, and flow of non-anticoagulated blood is metered by a peristaltic pump. The flow chamber contains a piece of the media of a pig aorta, cultured endothelial cells, smooth muscle cells or collagen-coated surfaces and human atherosclerotic plaques. After the experiment, the exposed material will be stained and examined for platelet and fibrin deposition. Drugs can be administered and tested for antithrombotic properties. This 
model for thrombosis has proven to be a workable system that closely mimics physiologic reality under standardised conditions.

\subsection{The thrombin generation curve}

The thrombin generation curve (TGC), one of the oldest tools of the clotting trade, has lately become the subject of renewed interest $[15,74,120,122-124,141-44]$. It contains all the relevant information on the physiological function of the coagulation system. The area under the curve (the endogenous thrombin potential (ETP) [142]) represents the total enzymatic action that thrombin can develop during its lifetime in plasma. In blood and in PRP, the ETP can be measured from a TGC obtained by subsampling. If a substrate with the right kinetic properties is added to plasma, thrombin generation can be monitored continuously as the first derivative of the product-time curve. At this moment, only chromogenic substrates have been described for this use so that the method is restricted to defibrinated PRP.

We demonstrated that higher than normal ETP is seen in all blood-based thrombosis-prone states tested, either congenital (e.g., deficiency of AT, protein $\mathrm{S}$ or protein C, factor V Leiden, prothrombin 20210A) or acquired (e.g., from the use of contraceptive pills). In coronary infarction, months after the acute phase as well as in patients presenting with a deep vein thrombosis, the ETP is increased. In the haemophilias (deficiency of Factors VII, DX and XI) the ETP is significantly lower than normal [145].

OAC treatment (INR $=1.5-3.0$ ) decreases the ETP to $20-40 \%$ of normal. Heparin administration in the therapeutic range has the same effect. The ETP also accurately reflects the effect of mixed OAC and heparin treatment. Platelet aggregation inhibitors diminish thrombin generation in PRP. In fact, we encountered no anticoagulant that would not decrease the ETP in PRP, and no antiplatelet agent that would not inhibit the ETP in PRP. This made us think that the ETP in PRP might be a useful model for antithrombotic action.

\section{Scientific rationale}

The HTS is traditionally seen as the result of the sequential action of primary and secondary haemostasis. The first, reflected in the bleeding time, is considered to be a platelet function and its overshoot is the arterial, platelet-rich thrombus. The second is seen as an activity of the plasmatic clotting mechanism; the plasma clotting time is considered the relevant test and venous thrombosis the pathological derailment.

The separation has been artificially stressed because platelet adhesion and aggregation are studied in anticoagulated blood, and clotting in platelet-free plasma. Under these experimental circumstances the co-operation between platelets and coagulation is artificially prevented. The impressive increase of our knowledge of the details of the clotting mechanism and platelet function tends to favour further subdivision. This is reflected in drug research. Not only is a sharp distinction made between anticoagulants and platelet inhibitors, but often a more restricted target is defined (e.g., Factor VIIan or G-proteins) and screening is for an action on that target rather than on global functioning of the HTS.

It is becoming increasingly clear that, in vivo, the HTS functions by the concerted action of platelets and plasma, rather than as a consequence of an adhesion-aggregation function of the platelets and a clotting function of the plasma (Figure 1). Thrombin is the most potent platelet activator, and platelet activation is essential for thrombin generation. 
Figure 1: Outlines of the interactions between the coagulation system and the platelet glycoprotein (GP) IIb/WIa and GPIb receptors (from[123]).

VWF: von Willebrand factor.

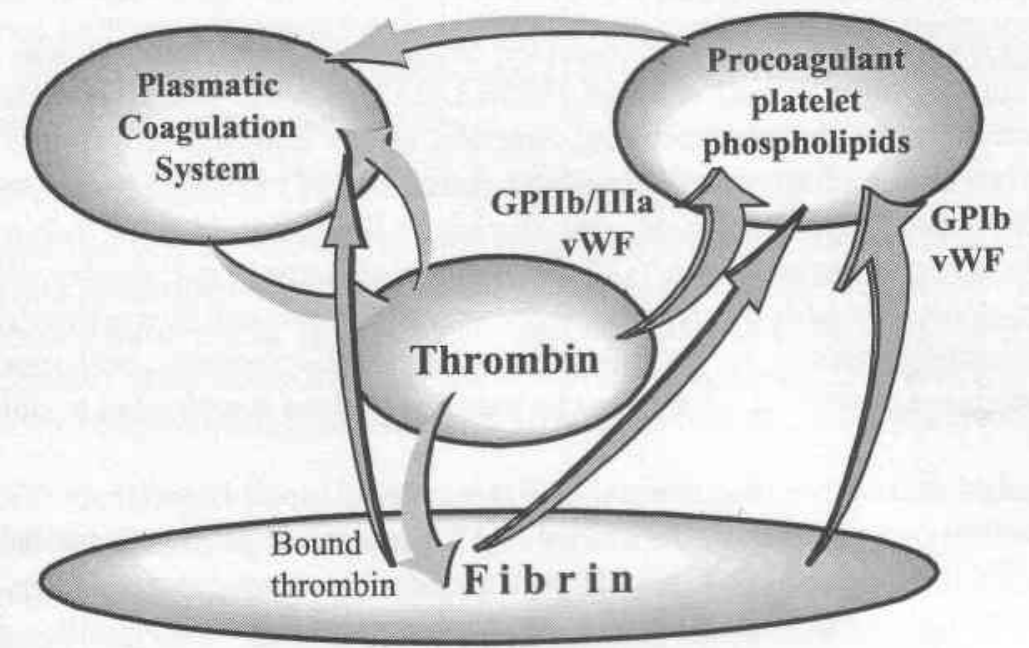

Anticoagulants inhibit arterial as well as venous thrombosis [146,147]. Platelet inhibitors inhibit thrombin generation in PRP, etc.

This is not the place to discuss the mechanisms in detail. We refer to books and review articles for this purpose. Here we only sketch outlines, together with some recent findings that may have an important bearing on drug development.

In the plasmatic coagulation system, Factor $\mathrm{Xa}$ is formed by the action of the TF-VIa. Factor $\mathrm{Xa}$ binds to TFPI, and the TFPI-Xa complex inhibits the TF-VIIa complex. Thrombin activates Factors V, VIII and XI and so accelerates its own generation, but it also binds to thrombomodulin and so starts the protein $\mathrm{C}$ mechanism that breaks down Factors $\mathrm{V}$ and VIII, thus indirectly inhibiting further thrombin generation. An important fraction $(\sim 30 \%)$ of all thrombin formed in clotting plasma is bound to the fibrin clot. Clot-bound thrombin does retain its thrombotic properties; it can clot fibrinogen, activate Factors V, VIII and XI and platelets $[123,148,149]$. It is not inhibited by AT and, upon fibrinolysis, it may reappear in circulation.

Four different thrombin receptors have been described on the platelet membrane. Thrombin action causes GPIIb/IIIa receptors in the platelet membrane to bind fibrinogen, which causes platelet aggregation. GPIb/IIl activation also leads to the exposure of procoagulant phospholipids in a vWF-dependent reaction [123,124]. These phospholipids are required for the proper activation of Factor $\mathrm{X}$ and prothrombin. Lately, the picture has been complicated by the discovery that fibrin, previously thought to be the inert end product of coagulation, plays an active role itself. It binds and activates vWF, which in turn activates platelets via $\mathrm{GPIb}$, and provokes the exposure of procoagulant phospholipids via an alternative pathway.

Thus, the co-operation between platelets and the coagulation system is central to the HTS, and the mechanism shows an abundance of positive and negative (often nested) feedback loops. This necessarily is a non-linear system [150]. In the most simple terms this means that the dose-response relationships become highly unpredictable ('chaotic'). Furthermore, thrombin generation reactions often go to completion, so that classical initial rate kinetics is 
of limited applicability. The literature abounds with studies that conjecture on antithrombotic effects of enzyme inhibition on the basis of oversimplified models. Extensive experience in enzyme kinetics tells us that our knowledge of the system (and of non-linear systems in general) is simply insufficient to predict such effects. We may be glad if we can understand certain phenomena a posteriori.

An example is the much-debated issue of inhibition of Factor Xa. The original idea was that it was more efficient to inhibit the prothrombin-converting enzyme (Factor $\mathrm{Xa}$ ) than the product (thrombin) $[151,152]$. This seemed a very logical idea until it was fully recognised that, under physiological circumstances, Factor Xa requires thrombin-activated Factor $V$ to increase its turnover number [154], and needs adsorption onto procoagulant phospholipid to decrease its $\mathrm{K}_{\mathrm{m}}$ below the plasma concentration of prothrombin [153]. The amount of prothrombin-converting complex that can be maximally formed is not higher than the scarcest component. In PRP, with adequate amounts of phospholipid added, it is easily seen that the rate-limiting component is not Factor $\mathrm{Xa}$. The reasons are:

- the plasma concentration of Factor $X$ is approx. $120 \mathrm{nM}$, whilst that of Factor $V$ is approx. $20 \mathrm{nM}$, which may rise to $40 \mathrm{nM}$ if the platelets release their Factor V [155]

- the serum concentration of Factor $X$ is considerable ('stable factor'), whereas that of Factor $\mathrm{V}$ is near to zero ('labile factor')

- decrease of the Factor Va concentration via the APC system efficiently limits prothrombin conversion.

In PRP, the rate limiting component is neither Factor Va nor Factor Xa, but the exposure of procoagulant phospholipids by the platelets [120]. Still closer to real life, if the procoagulant phospholipid surface is much larger than the molecules involved, as in the case of platelets sticking to a wounded surface, the reaction is diffusion-limited and therefore no longer dependent even upon the concentration of the prothrombinase complex on the surface. Only the concentration of prothrombin in the plasma counts [156-158]. Therefore, there are many arguments to show that, in clotting plasma, Factor Xa is available in excess and has to be inhibited by $90 \%$ in order to inhibit prothrombinase activity by $50 \%$.

Still, it is often argued that one can expect from direct Factor Xa inhibition an efficacy:safety ratio superior to that achieved by inhibiting thrombin once it is formed. There is no rational theoretical basis for this statement as soon as one realises the importance of thrombinmediated feedback reactions, and the excess of Factor Xa present in clotting plasma. This does not mean to say that Factor Xa inhibition may not be the mechanism via which good antithrombotic efficiency can be obtained. If it is pushed far enough it may certainly cause inhibition of prothrombin conversion. It is only meant as an illustration that predictions on the basis of available theory are precarious. At a previous state of knowledge, one would expect a benefit of Factor Xa inhibition. At present, one would rather predict a narrow therapeutic margin (viz. that between $90-100 \%$ inhibition of Factor X). It is the very essence of this article to show that even sophisticated theoretical arguments cannot predict the in vivo behaviour of an antithrombotic, but that a physiological test of the overall function of the HTS is needed instead. Nevertheless, it is a rewarding operation to refute theoretical considerations that are no longer up-to-date, but that tend to survive in pharmaceutical circles.

The proof of the pudding will remain in the eating. It has been shown that thrombin generation can be effectively inhibited by the injection of the pentasaccharide with anti-Factor Xa 
activity [159]. This pentasaccharide (Sanofi [SP/90107]; Organon [Org31540]) is now in Phase II clinical trials. DX9065a (Daiichi) is in Phase I clinical trial and TFPI SC59735 is in Phase II. If there are any specific advantages of Factor Xa inhibition they will be seen in such studies.

\section{Potential development issues}

\subsection{Catalysts of physiological inhibition}

\subsubsection{Purer preparations of the active fractions within natural heparins}

Heparins, as they are presently obtained from natural sources, are highly heterogeneous [14]. Apart from the anticoagulant molecules, there is $50-80 \%$ of other material that is not necessarily without biological action. Also, it has been postulated on good grounds that material with a molecular weight lower than 5400 is much less active than higher molecular weight material [160-162], whereas material larger than about 9000 has an extremely low bioavailability [16]. In addition, it might be more haemorrhagic than lower molecular weight material [18].

\subsubsection{Synthetic heparins}

It has been an important achievement of Petitou (within the Choay group) to synthesise the pentasaccharide that is responsible for high affinity AT binding in natural heparins. Later research in the Sanofi and Organon teams has led to variants with higher activity $[163,164]$. These materials have anti-Xa activity only. High doses can be given, however, so that thrombin generation can be inhibited in this way. In view of the much greater efficiency of AT action than of anti-Xa activity, it is to be expected that heparins in which a long inert glycosaminoglycan chain is attached to the active pentasaccharide would make a pure and very active heparin.

\subsubsection{Activators of heparin co-Factor II}

Dermatan sulfate and pentosan polyphosphate are long since known as antithrombotics $[20,164,165]$. These drugs have the drawback that concentrations above the micromolar range have to be administered, which at a molecular weight of 10,000 to 100,000 requires administration of large amounts of therapeutic material. The development of pure, low molecular weight material should be considered. There is only $1 \mu \mathrm{MHCII}$ in plasma. This is lower than the level of prothrombin $(2 \mu \mathrm{M})$. Optimal activation of all $\mathrm{HCII}$ will not exhaust the thrombin-forming capacity of the plasma. Unlike heparin, which acts on $2.4 \mu \mathrm{M} \mathrm{AT}$, activators of $\mathrm{HCII}$ cannot, therefore, be overdosed to cause bleeding.

A special class of substances, the thioxylosides, is capable of altering synthetic reactions in the body of glycosaminoglycans that interact with HCII. Administration of these drugs raises the level of glycosaminoglycans in the plasma, and in this way activate HCI $[166,167]$.

\subsection{Direct inhibitors}

Enormous progress has been made in our understanding of the stereochemistry of clotting enzymes [168]. This, together with modern techniques of organic synthesis and screening of inhibitory activity [34], has provided us with a number of highly specific inhibitors of individual clotting enzymes, and no doubt more are to come. Sanderson and Naylor-Olsen [169] recently published an excellent review on thrombin inhibitor design, to which we 
refer you for details. The hope is that from this line of research a compound will be identified that can be administered orally, and that has pharmacokinetic properties which allow standard dosage without control. Evidently, one of the problems is the large amount of serine proteases present in the intestinal tract.

It will be clear from the above discussion that, in our opinion, there is no predictable relation between the biochemical mode of action of these inhibitors and the pharmacological efficiency. Elg et al. compared the kinetic constants of eight different direct thrombin inhibitors and saw that, despite a 50,000-fold difference in $\mathrm{K}_{\mathrm{i}}$ value, hirudin and melagatran had similar antithrombotic effects at around $0.14 \mu \mathrm{M}$ plasma concentration [129]. These authors did report a relation between $\mathrm{k}_{\mathrm{on}}$ and the slope of the dose-response curve of thrombus inhibition. In theory, a steeper slope indicates a narrower therapeutic interval. To judge inhibitors on this criterion does not seem realistic, however, as long as we are not certain that the pharmacokinetics allow maintenance of stable plasma levels and, more importantly, as long as the dose-response of haemorrhage is not known.

\subsection{Platelet inhibitors}

At this moment, there are no inhibitors in clinical use that attack via GP Ib/LX, the receptor absent in Bernard-Soulier's disease. Antibodies against this inhibitor also strongly ( $50 \%)$ inhibit thrombin generation. A combination of antibodies against both the GP Ib and the GP $\mathrm{\Pi b} / \mathrm{Wl} /$ II a receptors will almost completely abolish thrombin generation in PRP. vWF has been shown to be a necessary co-factor for both receptors; consequently, in the absence of this factor thrombin generation is almost nil, independent of the availability of Factor VIII. This suggests that interfering with these interactions can be an efficient means of antithrombotic action.

We saw that fibrin can play an active role in the development of platelet procoagulant activity, and hence in thrombin generation and further thrombus growth. It may be interesting to try and find inhibitors of the (vWF-mediated) platelet-fibrin interaction, which might lead to early pacification of a growing thrombus.

\section{Editorial analysis}

In the search for new and better antithrombotics, the open options are as big as the number of vulnerable sites in the HTS (i.e., every enzyme and every receptor involved) multiplied by the number of compounds that can inhibit each site). It is hard to believe that the ideal antithrombotic is not there to be found. The question is how to find it. The present strategy is to first define a subsystem of interest within the HTS; this clotting factor, that membrane receptor. Then a test is set up for that subsystem. Promising compounds are selected on the basis of their performance in that test. Such compounds are then tested in animal thrombosis models and may make it to the phases of investigation in humans.

The problem lies in the choice of the subsystem to be tested. Clotting times and platelet aggregation/adhesion assays are only of limited use because they do not reflect interactions between platelets and the clotting system, recently shown to be extremely important. More specific tests on individual clotting factors or platelet functions are even less fit for the task. The risk is that we find inhibitors of an irrelevant test, and pass by good antithrombotics that do not inhibit this test. The example of LMWHs is a good illustration. These drugs were developed upon the criterion of Factor Xa inhibition, which later was shown to be of no relevance. Later research showed that the performance of these drugs is due to 
thrombin-inhibition together with high bioavailability and, probably, absence of large molecular weight molecules that induce bleeding.

Therefore, there is an obvious need for a representative, functional test of the HTS. This test should respond quantitatively in the same manner to any antithrombotic given at a dosage within its therapeutic window. It should, for example, be equally sensitive to doses of antiplatelet drugs and anticoagulants of comparable efficacy.

There are two tests in which the interaction between platelets and plasma is not artificially disrupted: thrombin generation in PRP (or whole blood), and flow chamber experiments in which non-anticoagulated human blood is drawn over a thrombogenic surface. Both tests require much development. In our opinion, progress in technical development of this type of test would be a major step forward in the search for the ideal anticoagulant.

\section{Bibliography}

Papers of special note have been highlighted as:

- of interest

.. of considerable interest

1. KESSELS H, KESTER AD, HEMKER HC: Intrinsic and method-induced variation of the bleeding time and related parameters. Thromb. Haemost. (1994) 71:798-799.

2. AGNELLI G: Thrombin plays a pivotal role in vascular re-occlusion after PTCA and coronary thrombolysis. Cardiovasc. Res. (1996) 31:232-234.

3. BADIMON L, MEYER BJ, BADIMON JJ: Thrombin in arterial thrombosis. Haemostasis (1994) 24:69-80.

4. CHESEBRO JH, ZOLDHELYI P, BADIMON L, FUSTER V: Role of thrombin in arterial thrombosis: implications for therapy. Thromb. Haemost. (1991) 66:1-5.

5. CHESEBRO JH, RAUCH U, FUSTER V, BADIMON JJ: Pathogenesis of thrombosis in coronary artery disease. Haemostasis (1997) 27:12-18.

6. FITZGERALD GA: The human pharmacology of thrombin inhibition. [Coron. Artery Dis. (1997) 8(1):A4]. Coron. Artery Dis. (1996) 7:911-918.

- Excellent overview.

7. SCHECTER AD, GIESEN PL, TABY $O$ et al.: Tissue factor expression in human arterial smooth muscle cells. TF is present in three cellular pools after growth factor stimulation. J. Clin. Invest. (1997) 100:2276-2285.

8. TOSCHI V, GALLO R, LETTINO M et al.: Tissue factor modulates the thrombogenicity of human atherosclerotic plaques. Circulation (1997) 95:594-599.

9. WILCOX JN, SMITH KM, SCHWARTZ SM, GORDON D: Localization of tissue factor in the normal vessel wall and in the atherosclerotic plaque. Proc. Natl. Acad. Sci. USA (1989) 86:2839.

10. MARMUR JD, THIRUVIKRAMAN SV, FYFE BS et al: Identification of active tissue factor in human coronary atheroma. Circulation (1996) 94:1226.

11. HEEMSKERK IW, VUIST WM, FEIJGE MA, REUTELINGSPERGER CP, LINDHOUT T: Collagen but not fibrinogen surfaces induce bleb formation, exposure of phosphatidylserine, and procoagulant activity of adherent platelets: evidence for regulation by protein tyrosine kinase-dependent $\mathrm{Ca}^{2+}$ responses. Blood (1997) 90:2615.

12. MURRAY CJ, LOPEZ AD: Evidence-based health policy - lessons from the Global Burden of Disease Study. Science (1996) 274:740.

13. FUSTER VVM: Thrombosis in Cardiovascular Disorders. WB Saunders, Philadelphia, USA (1992).

14. BARROWCLIFFE T: Low Molecular Weight Heparins.

- Contains essential information on low molecular weight heparins. 
15. HEMKER HC, BEGUINS: The activity of heparin in the presence and absence of $\mathrm{Ca}^{2+}$ ions; why the anti-Xa activity of LMW heparins is about two times overestimated. Thromb. Haemost. (1993) 70:717.

16. BENDETOWICZ AV, BEGUIN S, CAPLAIN H, HEMKER HC: Pharmacokinetics and pharmacodynamics of a low molecular weight heparin (enoxaparin) after subcutaneous injection, comparison with unfractionated heparin-a three way cross over study in human volunteers. Thromb. Haemost. (1994) 71:305.

17. BENDETOWICZ AV, KAI H, KNEBEL $\mathrm{R}$ et al.: The effect of subcutaneous injection of unfractionated and low molecular weight heparin on thrombin generation in platelet rich plasma - a study in human volunteers. Thromb. Haemost. (1994) 72:705.

18. HEMKER HC, BEGUIN S, KAKKAR VV: Can the haemorrhagic component of heparin be identified? Or an attempt at clean thinking on a dirty drug [editorial]. Haemostasis (1996) 26:117.

19. TOLLEFSEN DM, BLANK MK: Detection of a new heparin-dependent inhibitor of thrombin in human plasma. J. Clin. Invest. (1981) 68:589.

20. DOL F, PETITOU M, CHOAY J, SIE P, HOUIN G, BONEU B: Pharmacological properties of dermatan sulfate, of a low molecular weight dermatan sulfate and of two oversulfated derivatives. Folia Haematol. Int. Mag. Klin. Morphol. Blutforsch (1989) 116:851.

21. DOL F, CARANOBE C, DUPOUY D et al.: Effects of increased sulfation of dermatan sulfate on its in vitro and in vivo pharmacological properties. Thromb. Res. (1988) 52:153.

BENDAYANP, BOCCALON H, DUPOUY D, BONEU B: Dermatan sulfate is a more potent inhibitor of clot-bound thrombin than unfractionated and low molecular weight heparins. Thromb. Haemost. (1994) 71:576.

23. LOSONCZY H, DAVID M, NAGY I: Effect of pentosan polysulfate on activated partial thromboplastin time, thrombin time, euglobulin clot lysis, and on tissue-type plasminogen activator and plasminogen activator inhibitor activities in patients with thromboembolic disease. Semin. Thromb. Hemost. (1991) 17:394.

24. MAURAY S, STERNBERG C, THEVENIAUX $J$ et al:: Venous antithrombotic and anticoagulant activities of a fucoidan fraction. Thromb. Haemost. (1995) 74:1280.

25. SCHENK JF, GLUSA E, RADZIWON P, BUTTI A, MARKWARDT F, BREDDIN HK: A recombinant hirudin (IK-HIR02) in healthy volunteers. II. Effects on platelet adhesion and platelet-induced thrombin generation time. Haemostasis (1996) 26:187.

26. SCHENK JF, GLUSA E, RADZIWON P, BUTTI A, MARKWARDT F, BREDDIN HK: A recombinant hirudin (IK-HIR02) in healthy volunteers. I. Effects on coagulation parameters and bleeding time. Haemostasis (1996) 26:140.

27. MARKWARDT F: The development of hirudin as an antithrombotic drug. Thromb. Res. (1994) 74:1.

28. WALSMANN P: Isolation and characterization of hirudin from Hirudo medicinalis. Semin. Thromb. Hemost. (1991) 17:83.

29. FITZGERALD D: Specific thrombin inhibitors in vivo. Ann. NY Acad. Sci. (1994) 714:41.

- Excellent overview.

30. GAST A, TSCHOPP TB, BAUMGARTNER HR: Thrombin plays a key role in late platelet thrombus growth and/or stability. Effect of a specific thrombin inhibitor on thrombogenesis induced by aortic subendothelium exposed to flowing rabbit blood. Arterioscler. Thromb. (1994) 14:1466.

31. HERAS M, CHESEBRO JH, PENNY WJ, BAILEY KR, BADIMON L, FUSTER V: Effects of thrombin inhibition on the development of acute platelet- thrombus deposition during angioplasty in pigs. Heparin versus recombinant hirudin, a specific thrombin inhibitor. Circulation (1989) 79:657.

32. JANG IK, GOLD HK, ZISKIND AA, LEINBACH RC, FALLON JT, COLLEN D: Prevention of platelet-rich arterial thrombosis by selective thrombin inhibition. Circulation (1990) 81:219. 
33. LEFKOVITS J, TOPOL EJ: Direct thrombin inhibitors in cardiovascular medicine. Circulation (1994) 90:1522.

34. LAM KS, SALMONSE, HERSH EM, HRUBY VJ, KAZMIERSKI WM, KNAPP RJ: A new type of synthetic peptide library for identifying ligand-binding activity. Nature (1991) 354:82.

35. OSTREM JA, AL-OBEIDI F, SAFAR P et al:: Discovery of a novel, potent, and specific family of Factor Xa inhibitors via combinatorial chemistry. Biochemistry (1998) 37:1053.

AROCAS V, ZINGALI RB, GUILLIN MC, BON C, JANDROT-PERRUS M: Bothrojaracin: a potent two-site-directed thrombin inhibitor. Biochemistry (1996) 35:9083.

CAPPELLO M, BERGUM PW, VLASUK GP, FURMIDGE BA, PRITCHARD DI, AKSOY S: Isolation and characterization of the tsetse thrombin inhibitor: a potent antithrombotic peptide from the saliva of Glossina morsitans morsitans. Am. J. Trop. Med. Hyg. (1996) $54: 475$.

38. FRIEDRICH T, KROGER B, BIALOJAN S et al.: A Kazal-type inhibitor with thrombin specificity from Rhodnius prolixus. J. Biol. Chem. (1993) 268:16216. HOFFMANN A, WALSMANN P, RIESENER G, PAINTZ M, MARKWARDT F: Isolation and characterization of a thrombin inhibitor from the tick ixodes ricinus. Pharmazie (1991) 46:209.

40. KODANIS, ISHIDA K, MURAKAMI M: Aeruginosin 103-A, a thrombin inhibitor from the cyanobacterium Microcystis viridis. J. Nat. Prod. (1998) 61:1046.

41. REBELLO SS, MILLER BV, BASLER GC, LUCCHESI BR: CVS-1123, a direct thrombin inhibitor, prevents occlusive arterial and venous thrombosis in a canine model of vascular injury. J. Cardiovasc. Pharmacol. (1997) 29:240.

A low molecular weight, selective thrombin inhibitor, inogatran, vs. heparin, in unstable coronary artery disease in 1209 patients. A double- blind, randomized, dose-finding study. Thrombin inhibition in Myocardial Ischaemia (TRIM) study group. Eur. Heart J. (1997) 18:1416.

3. URIUDA Y, WANG QD, GRIP L, RYDEN L, SJOQUIST PO, MATTSSON C: Antithrombotic activity of inogatran, a new low-molecular-weight inhibitor of thrombin, in a closed-chest porcine model of coronary artery thrombosis. Cardiovasc. Res. (1996) 32:320.

URIUDA Y, WANG QD, HATORI N et al:: Coronary thrombosis/thrombolysis in pigs: effects of heparin, ASA, and the thrombin inhibitor inogatran. J. Pharmacol. Toxicol. Methods (1998) 39:81.

45.

46. GUSTAFSSON D, ANTONSSON T, BYLUND $R$ et al: : Effects of melagatran, a new GUSTAFSSON D, ELG M, LENFORS S, BORJESSON I, TEGER-NILSSON AC: Effects of inogatran, a new low-molecular-weight thrombin inhibitor, in rat models of venous and arterial thrombosis, thrombolysis and bleeding time. Blood Coagul. Fibrinolysis (1996) 7:69. low-molecular-weight thrombin inhibitor, on thrombin and fibrinolytic enzymes. Thromb. Haemost. (1998) 79:110.

MEHTA JL, CHEN L, NICHOLS WW, MATTSSON C, GUSTAFSSON D, SALDEEN TG: Melagatran, an oral active-site inhibitor of thrombin, prevents or delays formation of electrically induced occlusive thrombus in the canine coronary artery. $J$. Cardiovasc. Pharmacol. (1998) 31:345.

48. ROUX S, TSCHOPP T, BAUMGARTNER HR: Effects of napsagatran (Ro 46-6240), a new synthetic thrombin inhibitor and of heparin in a canine model of coronary artery thrombosis: comparison with an ex vivo annular perfusion chamber model. J. Pharmacol. Exp. Ther. (1996) 277:71.

- $\quad$ References 13-15: a few examples among many others of thrombin inhibitors.

49. BRADY SF, STAUFFER KJ, LUMMA WC et al.: Discovery and development of the novel potent orally active thrombin inhibitor N-(9-hydroxy-9-fluorenecarboxy)prolyl trans-4aminocyclohexylmethyl amide (L-372,460): coapplication of structure- based design and rapid multiple analogue synthesis on solid support. J. Med. Chem. (1998) 41:401.

50. CADROYY, CARANOBEC, BERNAT A, MAFFRANDJP,SIEP, BONEU B: Antithrombotic and bleeding effects of a new synthetic direct thrombin inhibitor and of standard heparin in the rabbit. Thromb. Haemost. (1987) 58:764. 
51. CIRILLO R, LIPPI A, SUBISSI A, AGNELLI G, CRISCUOLI M: Experimental pharmacology of hirunorm: a novel synthetic peptide thrombin inhibitor. Thromb. Haemost. (1996) 76:384.

52. DESCHENES I, FINKLE CD, WINOCOUR PD: Effective use of BCH-2763, a new potent injectable direct thrombin inhibitor, in combination with tissue plasminogen activator (tPA) in a rat arterial thrombolysis model. Thromb. Haemost. (1998) 80:186.

53. FINKLE CD, ST. PIERRE A, LEBLOND L, DESCHENES I, DIMAIO J, WINOCOUR PD: BCH-2763, a novel potent parenteral thrombin inhibitor, is an effective antithrombotic agent in rodent models of arterial and venous thrombosis-comparisons with heparin, r-hirudin, hirulog, inogatran and argatroban. Thromb. Haemost. (1998) 79:431.

54. GRIFFIN LC, TOOLE JJ, LEUNG LL: The discovery and characterization of a novel nucleotide-based thrombin inhibitor. Gene (1993) 137:25.

55. HARA H, TAMAO Y, KIKUMOTO R, OKAMOTO S: Effect of a synthetic thrombin inhibitor MCI-9038 on experimental models of disseminated intravascular coagulation in rabbits. Thromb. Haemost. (1987) 57:165.

56. HIJIKATE A, OKAMOTO S, IKEZAWA K, KIKIMOTO R, TONOMURA S, TAMAO Y: Proceedings: animal experiments of a new synthetic thrombin-inhibitor, dansyl-arginine-methyl-piperidine amide. Thromb. Diath. Haemorrh. (1975) 34:347.

57. HUSSAIN MA, KNABB R, AUNGST BJ, KETTNER C: Anticoagulant activity of a peptide boronic acid thrombin inhibitor by various routes of administration in rats. Peptides (1991) 12:1153.

58. IKOMA H, OHTSU K, TAMAO Y et al.: Effect of a potent thrombin inhibitor, No. 407, on novel experimental thrombosis generated by acetic acid. Kobe J. Med. Sci. (1980) 26:33.

59. KAISER B, HAUPTMANN J, WEISS A, MARKWARDT F: Pharmacological characterization of a new highly effective synthetic thrombin inhibitor. Biomed. Biochim. Acta (1985) 44:1201.

60. OKAYAMA T, ARAKI S, MIYAMAE T, MORITA Y, MORIKAWA T, HAGIWARA M: Anticoagulant activity of the novel thrombin inhibitor 1-butyl-3-(6,7dimethoxy-2-naphthylsulfonyl) amino-3-(3-guanidinopropyl)-2- pyrrolidinone hydrochloride. Arzneimittelforschung (1997) 47:1023.

61. NOESKE-JUNGBLUT C, HAENDLER B, DONNER P, ALAGON A, POSSANI L, SCHLEUNING WD: Triabin, a highly potent exosite inhibitor of thrombin. J. Biol. Chem. (1995) 270:28629.

62. RUPIN A, MENNECIER P, LILA C, DE NANTEUIL G, VERBEUREN TJ: Selection of S18326 as a new potent and selective boronic acid direct thrombin inhibitor. Thromb. Haemost. (1997) 78:1221.

63. SHUMAN RT, GESELLCHEN PD: Development of an orally active tripeptide arginal thrombin inhibitor. Pharm. Biotechnol. (1998) 11:57.

64. TAPPARELLI C, METTERNICH R, EHRHARDT $\mathrm{C}$ et al.: In vitro and in vioo characterization of a neutral boron-containing thrombin inhibitor. J. Biol. Chem. (1993) 268:4734.

65. TREMOLI E, COLLI S, PAOLETTI R: GYKI 14,451, a synthetic tripeptide inhibitor of thrombin: 'in vitro' and 'in vivo' studies. Adv. Exp. Med. Biol. (1984) 164:187.

66. BAGDY D, BARABAS E, FITTLER Z et al.: Experimental oral anticoagulation by a directly acting thrombin inhibitor (RGH-2958). Folia Haematol. Int. Mag. Klin. Morphol. Blutforsch
(1988) 115:136.

67. ANDERSEN K, DELLBORG M: Heparin is more effective than inogatran, a low-molecular weight thrombin inhibitor in suppressing ischemia and recurrent angina in unstable coronary disease. Thrombin Inhibition in Myocardial Ischemia (TRIM) Study Group. Am. J. Cardiol. (1998) 81:939.

68. LUNVEN C, GAUFFENY C, LECOFFRE C, O'BRIEN DP, ROOME NO, BERRY CN: Inhibition by Argatroban, a specific thrombin inhibitor, of platelet activation by fibrin clot-associated thrombin. Thromb. Haemost. (1996) 75:154. 
69. APITZ-CASTRO $R$, BEGUIN S, TABLANTE A, BARTOLI F, HOLT JC, HEMKER HC: Purification and partial characterization of draculin, the anticoagulant factor present in the saliva of vampire bats (Desmodus rotundus). Thromb. Haemost. (1995) 73:94.

DUNWIDDIE C, THORNBERRY NA, BULL HG et al.: Antistasin, a leech-derived inhibitor of Factor Xa. Kinetic analysis of enzyme inhibition and identification of the reactive site. J. Biol. Chem. (1989) 264:16694.

References 20 \& 21; two among the many natural Factor Xa inhibitors.

71. DUNWIDDIE CT, SMITH DE, NUTT EM, VLASUK GP: Anticoagulant effects of the selective Factor XA inhibitors tick anticoagulant peptide and antistasin in the APTT assay are determined by the relative rate of prothrombinase inhibition. Thromb. Res. (1991) 64:787.

DUNWIDDIE CT, NEEPER MP, NUTT EM et al.: Site-directed analysis of the functional domains in the Factor $X_{a}$ inhibitor tick anticoagulant peptide: identification of two distinct regions that constitute the enzyme recognition sites. Biochemistry (1992) 31:12126.

HAUPTMANN J, KAISER B: Anticoagulant and antithrombotic action of the Factor Xa inhibitor antistasin (ATS). Thromb. Res. (1993) 71:169.

HERAULT JP, BERNAT A, PFLIEGER AM, LORMEAU JC, HERBERT JM: Comparative effects of two direct and indirect Factor $X a$ inhibitors on free and clot-bound prothrombinase. J. Pharmacol. Exp. Ther. (1997) 283:16.

JORDAN SP, WAXMAN L, SMITH DE, VLASUK GP: Tick anticoagulant peptide: kinetic analysis of the recombinant inhibitor with blood coagulation Factor Xa. Biochemistry (1990) 29:11095.

KATAKURA S, NAGAHARA T, HARA T, IWAMOTO M: A novel Factor Xa inhibitor: structure-activity relationships and selectivity between Factor $\mathrm{Xa}$ and thrombin. Biochem. Biophys. Res. Commun. (1993) 197:965. 78. MAO SS, HUANG J, WELEBOB C, NEEPER MP, GARSKY VM, SHAFER JA: Identification potency toward human Factor Xa. Biochemistry (1995) 34:5098.

MORISHIMA Y, TANABE K, TERADA Y, HARA T, KUNITADA S: Antithrombotic and hemorrhagic effects of DX-9065a, a direct and selective Factor Xa inhibitor: comparison with a direct thrombin inhibitor and antithrombin III-dependent anticoagulants. Thromb. Haemost. (1997) 78:1366.

NUTT E, GASIC T, RODKEY J et al.: The amino acid sequence of antistasin. A potent inhibitor of Factor Xa reveals a repeated internal structure. J. Biol. Chem. (1988) 263:10162.

NUTT EM, JAIN D, LENNY AB, SCHAFFER L, SIEGL PK, DUNWIDDIE CT: Purification and characterization of recombinant antistasin: a leech-derived inhibitor of coagulation Factor Xa. Arch. Biochem. Biophys. (1991) 285:37.

PRASA D, SVENDSEN L, STURZEBECHER J: Inhibition of thrombin generation in plasma by inhibitors of Factor Xa. Thromb. Haemost. (1997) 78:1215.

SCHREUDER H, ARKEMA A, DE BOER B et al.: Crystallization and preliminary crystallographic analysis of antistasin, a leech-derived inhibitor of blood coagulation Factor Xa. J. Mol. Biol. (1993) 231:1137.

LASUK GP: Structural and functional characterization of tick anticoagulant peptide (TAP): a potent and selective inhibitor of blood coagulation Factor Xa. Thromb. Haemost. (1993) 70:212. novel inhibitor of blood coagulation Factor Xa. Science (1990) 248:593.

YAMAZAKI M, ASAKURA H, AOSHIMA K et al.: Effects of DX-9065a, an orally active, newly synthesized and specific inhibitor of Factor $\mathrm{Xa}$, against experimental disseminated intravascular coagulation in rats. Thromb. Haemost. (1994) 72:392.

JOHNSON K, HUNG D: Novel anticoagulants based on inhibition of the Factor VIIa/tissue factor pathway. Coron. Artery Dis. (1998) 9:83. 
88. HUANG M, SYED R, STURA EA et al.: The mechanism of an inhibitory antibody on

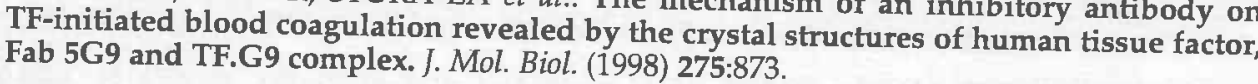

89. HARKER LA, HANSON SR, WILCOX JN, KELLY AB: Antithrombotic and antilesion benefits without hemorrhagic risks by inhibiting tissue factor pathway. Haemostasis (1996)
26:76.

90. ORVIM U, BARSTAD RM, ORNING L et al.: Antithrombotic efficacy of inactivated active site recombinant Factor VIIa is shear dependent in human blood. Arterioscler. Thromb. Vasc.
Biol. (1997) 17.3049.

91. KJALKE M, OLIVER JA, MONROE DM et al.: The effect of active site-inhibited Factor VIIa on tissue factor- initiated coagulation using platelets before and after aspirin administration. Thromb. Haemost. (1997) 78:1202.

92. RAGNI M, GOLINO P, CIRILLO P et al.: Inactivated Factor VII exercises a powerful antithrombotic activity in an experimental model of recurrent arterial thrombosis.
Cardiologia (1996) 41:51.

93. RONNING HF, RISOEN UC, ORNING L, SLETTEN K, SAKARIASSEN KS: Synthetic peptide analogs of tissue factor and Factor VII which inhibit Factor Xa formation by the
tissue factor/Factor VIIa complex. Thromb. Res. (1996) $84: 73$.

94. RAGOSTA M, GIMPLE LW, GERTZ SD et al: Specific Factor Xa inhibition reduces restenosis after balloon angioplasty of atherosclerotic femoral arteries in rabbits.
Circulation (1994) 89:1262.

95. LEFKOVITS J, MALYCKY JL, RAO JS et al: Selective inhibition of Factor Xa is more efficient than Factor VIIa- tissue factor complex blockade at facilitating coronary thrombolysis in the canine model. J. Am. Coll. Cardiol. (1996) 28:1858.

96. BENEDICT CR, RYAN J, TODD J et al:: Active site-blocked Factor Xa prevents thrombus formation in the coronary vasculature in parallel with inhibition of extravascular coagulation in a canine thrombosis model. Blood (1993) 81:2059.

97. FITZGERALD GA, MEAGHER EA: Antiplatelet drugs. Eur. J. Clin. Invest. (1994) 24(Suppl.
1):46. 98. VERSTRAETE M: Modulating platelet function with selective thrombin inhibitors.
Haemostasis (1996) 26(Suppl 4):70.

99. MONCADA S, VANE JR: Arachidonic acid metabolites and the interactions between platelets and blood-vessel walls. New Engl. J. Med. (1979) 300:1142.

100. FITZGERALD GA: Dipyridamole. New Engl. J. Med. (1987) 316:1247.

101. GRESELE P, ARNOUT J, DECKMYN H, VERMYLEN J: Mechanism of the antiplatelet action of dipyridamole in whole blood: modulation of adenosine concentration and

102. OATES JA, FITZGERALD GA, BRANCH RA, JACKSON EK, KNAPP HR, ROBERTS LJD: Clinical implications of prostaglandin and thromboxane A2 formation (1). New Engl. J.
Med. (1988) 319:689.

103. OATES JA, FITZGERALD GA, BRANCH RA, JACKSON EK, KNAPP HR, ROBERTS LJD: Clinical implications of prostaglandin and thromboxane $\mathbf{A 2}$ formation (2). New Engl. J.
Med. (1988) 319:761.

104. NICOLINI FA, MEHTA JL, NICHOLS WW, SALDEEN TG, GRANT M: Prostacyclin analogue iloprost decreases thrombolytic potential of tissue-type plasminogen activator in canine coronary thrombosis. Circulation (1990) 81:1115.

105. TOPOL EJ, ELLIS SG, CALIFF RM et al.: Combined tissue-type plasminogen activator and prostacyclin therapy for acute myocardial infarction. Thrombolysis and Angioplasty in
Myocardial Infarction (TAMI) 4 Study Group. J. Am. Coll. Cardiol. (1989) 14:877.

106. DARIUS H, NIXDORFF U, ZANDER J, RUPPRECHT HJ, ERBEL R, MEYER J: Effects of ciprostene on restenosis rate during therapeutic transluminal coronary angioplasty.
Agents Actions Suppl. (1992) 37:305. 
107. FIDDLER GI, LUMLEY P: Preliminary clinical studies with thromboxane synthas inhibitors and thromboxane receptor blockers. A review. Circulation (1990) 81:I69.

108. VERSTRAETE M: The PACK trial: morbidity and mortality effects of ketanserin Prevention of Atherosclerotic Complications. Vasc. Med. (1996) 1:135.

109. Prevention of atherosclerotic complications: controlled trial of ketanserin. Prevention o Atherosclerotic Complications with Ketanserin Trial Group. Br. Med. J. (1989) 298:424.

110. DEFREYN G, BERNAT A, DELEBASSEE D, MAFFRAND JP: Pharmacology of ticlopidine a review. Semin. Thromb. Hemost. (1989) 15:159.

111. BALSANOF, RIZZON P, VIOLI F et al.: Antiplatelet treatment with ticlopidine in unstable angina. A controlled multicenter clinical trial. The Studio della Ticlopidina nell'Angin: Instabile Group. Circulation (1990) 82:17.

112. BOSSAVY JP, THALAMASC, SAGNARD L et al.: A double-blind randomized comparison of combined aspirin and ticlopidine therapy versus aspirin or ticlopidine alone or experimental arterial thrombogenesis in humans. Blood (1998) 92:1518.

113. HERBERT JM, BERNAT A, SAMAMA M, MAFFRAND JP: The anti-aggregating and antithrombotic activity of ticlopidine is potentiated by aspirin in the rat. Thromb. Haemost (1996) 76:94.

114. ROALD HE, BARSTAD RM, KIERULF P et al.: Clopidogrel-a platelet inhibitor which inhibits thrombogenesis in non- anticoagulated human blood independently of the blood flow conditions. Thromb. Haemost. (1994) 71:655.

115. TAYLOR FB, COLLER BS, CHANG AC et al.: 7E3 F(ab')2, a monoclonal antibody to the platelet GPIIb/IIIa receptor, protects against microangiopathic hemolytic anemia and microvascular thrombotic renal failure in baboons treated with $\mathrm{C} 4 \mathrm{~b}$ binding protein and a sublethal infusion of Escherichia coli. Blood (1997) 89:4078.

116. AMMAR T, SCUDDER LE, COLLER BS: In vitro effects of the platelet glycoprotein IIb/IIIa receptor antagonist c7E3 Fab on the activated clotting time. Circulation (1997) 95:614.

117. COLLER BS, ANDERSON KM, WEISMAN HF: The anti-GPIIb-IIIa agents: fundamental and clinical aspects. Haemostasis (1996) 26(Suppl. 4):285.

118. GOLD HK, COLLER BS, YASUDA $\mathrm{T}$ et al.: Rapid and sustained coronary artery recanalization with combined bolus injection of recombinant tissue-type plasminogen activator and monoclonal antiplatelet GPIIb/IIIa antibody in a canine preparation. Circulation (1988) 77:670.

119. COLLER BS: A new murine monoclonal antibody reports an activation-dependent change in the conformation and/or microenvironment of the platelet glycoprotein IIb/IIIa complex. J. Clin. Invest. (1985) 76:101.

120. BEGUIN S, LINDHOUT T, HEMKER HC: The effect of trace amounts of tissue factor on thrombin generation in platelet rich plasma, its inhibition by heparin. Thromb. Haemost. (1989) 61:25

121. KEULARTS IM, BEGUIN S, DE ZWAAN C, HEMKER HC: Treatment with a GPIIb/IIIa antagonist inhibits thrombin generation in platelet rich plasma from patients. Thromb. Haemost. (1998) 80:370.

122. REVERTER JC, BEGUIN S, KESSELS H, KUMAR R, HEMKER HC, COLLER BS: Inhibition of platelet-mediated, tissue factor-induced thrombin generation by the mouse/human chimeric 7E3 antibody. Potential implications for the effect of c7E3 Fab treatment on acute thrombosis and 'clinical restenosis'. J. Clin. Invest. (1996) 98:863.

- First demonstration that an anti-aggregant does influence thrombin generation.

123. BEGUIN S, KUMAR R: Thrombin, fibrin and platelets: a resonance loop in which von Willebrand factor is a necessary link. Thromb. Haemost. (1997) 78:590.

124. BÉGUIN S, KUMAR R, KEULARTS I, SELIGSOHN U, COLLER BS, HEMKER HC: Fibrin-dependent platelet procoagulant activity requires GPIb receptors and von Willebrand factor. (1999) Blood 93:564-70.

- Demonstration that fibrin is thrombogenic and acts through von Willebrand factor. 
125. CHIU HM, HIRSH J, YUNG WL, REGOECZI E, GENT M: Relationship between the anticoagulant and antithrombotic effects of heparin in experimental venous thrombosis.
Blood (1977) 49:171.

126. BASU D, GALLUS A, HIRSH J, CADE J: A prospective study of the value of monitoring heparin treatment with the activated partial thromboplastin time. New Engl. J. Med. (1972)
287:324.

127. HULL RD, RASKOB GE, HIRSH J et al.: Continuous intravenous heparin compared with intermittent subcutaneous heparin in the initial treatment of proximal-vein thrombosis. New Engl. J. Med. (1986) 315:1109.

128. ANAND S, GINSBERG JS, KEARON C, GENT M, HIRSH J: The relation between the activated partial thromboplastin time response and recurrence in patients with venous thrombosis treated with continuous intravenous heparin. Arch. Intern. Med. (1996)
156:1677.

129. ELG M, GUSTAFSSON D, DEINUM J: The importance of enzyme inhibition kinetics for the effect of thrombin inhibitors in a rat model of arterial thrombosis. Thromb. Haemost.

130. POLLER L, VAN DEN BESSELAAR AM, JESPERSEN J, TRIPODI A, HOUGHTON D: The European Concerted Action on Anticoagulation (ECAA): field studies of coagulometer effects on the ISI of ECAA thromboplastins. Thromb. Haemost. (1998) 80:615.

131. NOWAK G, BUCHA E: Quantitative determination of hirudin in blood and body fluids. Semin. Thromb. Hemost. (1996) 22:197.

132. BERRY CN, LUNVEN C, GIRARDOT C et al.: Ecarin clotting time: a predictive coagulation assay for the antithrombotic activity of argatroban in the rat. Thromb. Haemost. (1998)

133. SAKARIASSEN KS, AARTS PA, DE GROOT PG, HOUDIJK WP, SIXMA JJ: A perfusion chamber developed to investigate platelet interaction in flowing blood with human vessel wall cells, their extracellular matrix, and purified components. J. Lab. Clin. Med. (1983)

134. SAKARIASSEN KS, KUHN H, MUGGLI R, BAUMGARTNER HR: Growth and stability of thrombi in flowing citrated blood: assessment of platelet-surface interactions with computer-assisted morphometry. Thromb. Haemost. (1988) 60:392. 135. HANSON SR, SAKARIASSEN KS: Blood flow and antithrombotic drug effects. Am. Heart J.
(1998) 135:S132.

136. BADIMON L, BADIMON JJ, GALVEZ A, CHESEBRO JH, FUSTER V: Influence of arterial damage and wall shear rate on platelet deposition. Ex vivo study in a swine model.
Arteriosclerosis (1986) 6:312.

137. BOSSAVY JP, SAKARIASSEN KS, BARRET A, BONEU B, CADROY Y: A new method for quantifying platelet deposition in flowing native blood in an ex vivo model of human thrombogenesis. Thromb. Haemost. (1998) 79:162.

138. BARSTAD RM, ROALD HE, CUI Y, TURITTO VT, SAKARIASSEN KS: A perfusion chamber developed to investigate thrombus formation and shear profiles in flowing native human blood at the apex of well- defined stenoses. Arterioscler. Thromb. (1994)

139. HOLME PA, ORVIM U, HAMERS MJ et al.: Shear-induced platelet activation and platelet microparticle formation at blood flow conditions as in arteries with a severe stenosis. Arterioscler. Thromb. Vasc. Biol. (1997) 17:646.

140. DIQUELOU A, LEMOZY S, DUPOUY D, BONEU B, SAKARIASSEN K, CADROY Y: Effect of blood flow on thrombin generation is dependent on the nature of the thrombogenic
surface. Blood (1994) 84:2206.

141. HEMKER HC, WILLEMS GM, BEGUIN S: A computer assisted method to obtain the prothrombin activation velocity in whole plasma independent of thrombin decay
processes. Thromb. Haemost. (1986) 56:9.

142. HEMKER HC, BEGUIN S: Thrombin generation in plasma: its assessment via the endogenous thrombin potential. Thromb. Haemost. (1995) 74:134. 
143. HERAULT JP, PEYROU V, SAVI P, BERNAT A, HERBERT JM: Effect of SR121566A, a potent GP IIb-IIIa antagonist on platelet- mediated thrombin generation in vitro and in vivo. Thromb. Haemost. (1998) 79:383.

144. PEYROU V, BEGUIN S, BONEU B, HEMKER HC: The activity of unfractionated heparin and low molecular weight heparins in rabbit plasma-the need for using absolute anti-Factor $\mathrm{Xa}$ and antithrombin activities. Thromb. Haemost. (1997) 77:312.

145. WIELDERS S, MUKHERJEE M, MICHIELS J et al.: The routine determination of the endogenous thrombin potential, first results in different forms of hyper- and hypocoagulability. Thromb. Haemost. (1997) 77:629.

146. A double-blind trial to assess long-term oral anticoagulant therapy in elderly patients after myocardial infarction. Report of the Sixty Plus Reinfarction Study Research Group. Lancet (1980) 2:989.

147. NERI SERNERI GG, ROVELLI F, GENSINI GF, PIRELLI S, CARNOVALI M, FORTINI A: Effectiveness of low-dose heparin in prevention of myocardial reinfarction. Lancet (1987) 1:937.

- References 46 and 47 together demonstrate that thrombin inhibition inhibits arterial thrombi, independent of the mechanism of thrombin inhibition. .

148. KUMAR R, BEGUINS, HEMKER HC: The influence of fibrinogen and fibrin on thrombin generation-evidence for feedback activation of the clotting system by clot bound thrombin. Thromb. Haemost. (1994) 72:713.

149. KUMAR R, BEGUIN S, HEMKER HC: The effect of fibrin clots and clot-bound thrombin on the development of platelet procoagulant activity. Thromb. Haemost. (1995) 74:962.

150. HEMKER HC, HESS B: Analysis and Simulation of Biochemical Systems. Elsevier, Amsterdam, Holland (1972).

151. YIN ET, WESSLER S, STOLL PJ: Biological properties of the naturally occurring plasma inhibitor to activated Factor X. J. Biol. Chem. (1971) 246:3703.

152. WESSLERS, YINET: Theory and practice of minidose heparin in surgical patients. A status report. Circulation (1973) 47:671.

153. ROSING J, TANS G, GOVERS-RIEMSLAG JW, ZWAAL RF, HEMKER HC: The role of phospholipids and Factor Va in the prothrombinase complex. J. Biol. Chem. (1980) 255:274.

154. PIETERS ], LINDHOUT T, HEMKER HC: In situ-generated thrombin is the only enzyme that effectively activates Factor VIII and Factor V in thromboplastin-activated plasma. Blood (1989) 74:1021.

155. BARUCH D, HEMKER HC, LINDHOUT T: Kinetics of thrombin-induced release and activation of platelet Factor V. Eur. J. Biochem. (1986) 154:213.

156. BILLY D, SPEIJER H, LINDHOUT T, HEMKER HC, WILLEMS GM: Inhibition of prothrombinase at macroscopic lipid membranes: competition between antithrombin and prothrombin. Biochemistry (1995) 34:13699.

157. BILLY D, SPEIJER H, WILLEMS G, HEMKER HC, LINDHOUT T: Prothrombin activation by prothrombinase in a tubular flow reactor. J. Biol. Chem. (1995) 270:1029.

158. BILLY D, BRIEDE J, HEEMSKERK JW, HEMKER HC, LINDHOUT T: Prothrombin conversion under flow conditions by prothrombinase assembled on adherent platelets. Blood Coagul. Fibrinolysis (1997) 8:168.

159. LORMEAU JC, HERAULT JP: The effect of the synthetic pentasaccharide SR 90107/ORG 31540 on thrombin generation ex vivo is uniquely due to ATIII-mediated neutralization of Factor Xa. Thromb. Haemost. (1995) 74:1474.

160. BEGUINS, LINDHOUT T, HEMKER HC: The mode of action of heparin in plasma. Thromb. Haemost. (1988) 60:457.

- Demonstration that anti-Factor Xa activity of heparin contributes little to heparin action.

161. BEGUIN S, MARDIGUIAN J, LINDHOUT T, HEMKER HC: The mode of action of low molecular weight heparin preparation (PK10169) and two of its major components on thrombin generation in plasma. Thromb. Haemost. (1989) 61:30. 
BEGUIN S, WIELDERS S, LORMEAU JC, HEMKER HC: The mode of action of CY216 and
CY222 in plasma. Thromb. Haemost. (1992) 67:33.

163.

PETITOU M, DUCHAUSSOY P, JAURAND G et al.: Synthesis and pharmacological 31540). J. Med. Chem. (1997) 40:1600 an antithrombotic pentasaccharide (SR 90107A/ORG

164.

PETTTOU M, DUCHAUSSOY P, LEDERMAN I et al: Synthesis of heparin fragments. A chemical synthesis of the pentasaccharide O-(2-deoxy-2-sulfamido-6-O-sulfo-alpha-Dglucopyranosyl)-(1-4)-O-(beta-D-glucopyranosyluronic acid)-(1-4)-O-(2sulfo-alpha-L-ido-3,6-di-O-sulfo-alpha-D-glu copyranosyl)-(1-4)-O-(2-Osulfo-D-glucopyranose decasodium salt acid)-(1-4)-2-deoxy-2-sulfamido-6-Oantithrombin III. Carbohydr. Res. (1986) The first 147:221.

- The first synthesis of an active polysaccharide with heparin-action.

165.

DOL F, PETITOU M, LORMEAU JC et al.: Pharmacologic properties of a low molecular Med. (1990) 115:43.

166. AGUEJOUF O, OUALANE FA, INAMO J et al.: The arterial antithrombotic activity thioxylosides in a rat model of laser-induced thrombosis. Semin. Thromb. Hemost. (1996)
22:327.

167. BELLAMY F, HORTON D, MILLET J, PICART F, SAMRETH S, CHAZAN JB: Glycosylated derivatives of benzophenone, benzhydrol, and benzhydril as potential venous
antithrombotic agents. J. Med. Chem. (1993) 36:898.

168. BODE W, MAYR I, BAUMANN U, HUBER R, STONE SR, HOFSTEENGE J: The refined 1.9 A crystal structure of human alpha-thrombin: interaction with D-Phe-Pro-Arg chloromethylketone and significance of the Tyr-Pro-Pro-Trp insertion segment. Embo. J.
(1989) 8:3467.

- Classical paper on which much of the stereochemistry of thrombin inhibitors is based.

169. SANDERSON PE, NAYLOR-OLSEN AM: Thrombin inhibitor design. Curr. Med. Chem. 170. GIESSEN PLA et al.: Blood borne tissue factor. a new view on thrombosis. Proc. Natl. Acad.
Sci. USA (In Press).

H Coenraad Hemker ${ }^{\dagger}$, Peter LA Giesen, Robert Wagenvoord \& Suzette Béguin
${ }^{\dagger}$ Author for correspondence

Cardiovascular Research Institute Maastricht, PO Box 616, 6200MD Maastricht, The Netherlands

Tel.: +31 43 3881674; Fax: +31 43 3670988; Email: hc.hemker@bioch.unimaas.nl 